Journal of Social Sciences 7 (4): 495-497, 2011

ISSN 1549-3652

(C) 2011 Science Publications

\title{
Conservation and Development of Indigenous Knowledge of the Use of Water Buffaloes
}

\author{
Samanchai Suwanamphai, Songkoon Chantachon and Kosit Paengsoi \\ The Research Institute of Northeastern Art and Culture, \\ Mahasarakham University, Thailand
}

\begin{abstract}
Problem statement: The use of water buffalo labor for farming and tie between rice farmers and water buffaloes at present are greatly decreasing because rice farmers give more importance to modern ploughing machines than water buffaloes. Water buffalo rising and traditions and rituals involving them which have been useful to humans for a very long time almost all disappear from Isan (Northeast Thailand). The purposes were to examine current conditions and problems and indigenous knowledge of the use of water buffaloes and to investigate the process of conservation and development of the use of water buffaloes in different forms in Isan. The study was conducted in Isan covering 8 Changwats: Nakhon Phanom, Sakon Nakhon Nong Bua Lam Phu, Udon Thani, Khon Kaen, Ubon Ratchathani, Kalasin and Roi ET. Approach: The qualitative research methodology was used. Data was collected from related literature and field studies using structured and unstructured-interview forms, workshop and focus group discussion with 199 informants. The findings were presented by means of a descriptive analysis. Results: The conservation and development of indigenous knowledge of the use of water buffaloes in all the 8 Changwats of Isan had increasingly changed from the past. For water buffalo conservation at present, they have formed groups in cooperation with government agencies involved according to government policy in each period. The group members are not confident that their own group will be able to sustainably exist due to the factors which are the state policy in other parts involved. Some factors can impact the water buffalo conservation groups such as limited places for water buffalo rising, the buffalo rising places being changed to be pear tree farms, for planting eucalyptus trees and others. The uses of water buffaloes as labor and in different cultural rituals and traditions have decreased because the number of water buffalo risers is small; the indigenous knowledge of healing and health care of water buffaloes using herbal medicines and black magic which have been traditional beliefs has not been adhered to by anyone and the use of water buffalo manure has no development at all. Conclusion: In the past, humans and water buffaloes had great tie with one another. Farmers also used water buffaloes as labor in farming which could help save expensed create incomes and they are heritages for children in new generations. At present, there is very little water buffalo conservation. The development and adherence to the indigenous knowledge have been decreased. In some local areas these things have disappeared.
\end{abstract}

Key words: Water buffaloes, indigenous knowledge, conservation groups, herbal medicines

\section{INTRODUCTION}

The socio-culture of Isan people in the past had water buffaloes as a greatly important part of agriculture. It has been said that water buffaloes are national animals. Humans and water buffaloes had close tie to one another as life partners, particularly in the area of 8 Changwat of Isan where water buffaloes were generally used for ploughing rice fields. They were these 8 Changwat Naknon Phanom, Sakon Nakhon, Nong Bua Lam Phu, Udon Thani, Khon Kaen, Ubon Ratehathani, Kalasin and Roi Et. The use of water buffalo manure as fertilizer on the rice farm plots could make the soils rich. Water buffaloes were risk insurance, decreased poverty problems, were assets or home banks and could help create the natural balance and community ecological system. The use of water buffaloes with the lack of indigenous knowledge could

Corresponding Author: Samanchai Suwanamphai, The Research Institute of Northeastern Art and Culture, Mahasarakham University, Thailand 


\section{J. Social Sci., 7 (4): 495-497, 2011}

rapidly decrease the number of water buffaloes and the water buffaloes are being sold and are to disappear if there are no conservation and development of indigenous knowledge of the use of water buffaloes.

\section{MATERIALS AND METHODS}

The qualitative research methodology was used, Data were collected documents, related literature and field data were collected using structured and unstructured-interview forms and focus group discussion with 199 informants from a group of 73 key informants and experts, a group of 95 casual informants who raised water buffaloes or conserved indigenous knowledge of using water buffaloes and a group of 31 general informants who operated water buffalo trade business at cattle trade markets. The study findings were presented by means of a descriptive analysis.

\section{RESULTS}

For the background of conservation of the indigenous knowledge, it was found that in the past in every Changwat Isan farmers raised water buffaloes for ploughing rice fields. There were local sages of indigenous knowledge who predicted the characteristics of good and auspicious water buffaloes, pretty buffaloes, healing them with herbal medicines and beliefs, such different rituals as water buffalo spirit calling and water buffalo thanksgiving. At present, a very small number of water buffaloes are kept for labor use. However, some farmers still like raising them and are interested in conservation and adherence to the indigenous knowledge by forming groups of water buffalo raisers and conservation. They have continuous activities including the water buffalo conservation groups in every of all the 8 Changwat as mentioned above.

The development of the indigenous knowledge of the use of water buffaloes, it was found that water buffalo manure was used to make fertilizers for putting on rice field plots, plants and different vegetables. In the past, farmers like using dry and wet manure which was not convenient to use. At present, farmers have developed it to be packed water-buffalo manure fertilizers and fill it in sacks to be convenient to use and to generate added values, to create community incomes both directly and indirectly.

Currently it has been found that the farmers in small groups still have the value of water buffalo raising and they still use water buffaloes to plough their rice fields, for example, the rice farmers in these Changwat: Ubon Ratchathani, Surin, Buri Ram, Nakhon Phanom and Sakon Nakhon. Nevertheless, original traditions and culture gradually disappear such as the tradition of water-buffalo spirit calling on various occasions because there are no adherence and transference of the rituals to people of new generation, indigenous knowledge of village sages have been abandoned, farmers have turned to use ploughing machines instead of water buffalo labor and because the state sector pays little attention to the water buffalo raising groups. These reasons can cause the water buffalo raisers to lack a direction to develop and the farmers cannot rely on themselves. The problems found include: Lack of large budget and more necessarily, knowledge of conservation and development of the use of water buffaloes.

For the guidelines for conservation and development of the indigenous knowledge, there are very limited guidelines. The direction is unclear. Water buffalo raisers still lack confidence. Therefore, the state sector should provide more supports by promoting farmers to have conservation of water buffalo raising, using indigenous knowledge to use water buffalo labor by pushing it into the learning-teaching process in the educational institution curriculum at every level in continuity (Arayesh, 2010).

\section{DISCUSSION}

The findings of this study of conservation and development of indigenous knowledge of the use of water buffaloes in 8 Changwat of Isan indicate that the rice farmer still have positive attitudes toward water buffaloes as animals which do great favors to humans in rice farming and they are valuable assets when necessary. Water buffaloes are an important part of rice farming. Humans and water buffaloes still have a close tie with each other as life partners. Water buffaloes are a part of the society, economy and culture and traditions. Rice farmers raise water buffaloes as friends and for solving the problem of poverty. They are cash animals. The Isan farmers ethnics are still interested in conserving by using the indigenous knowledge and developing the use of water buffaloes. They pround of the their identities of ethic group (Movahedi, 2011).

\section{CONCLUSION}

This study examined the background, current conditions and problems and guidelines for conservation and development of indigenous knowledge of the use of water buffaloes in various 
forms in 8 Changwat of Isan: Nakhon Phanom, Sakon Nakhon, Nong Bua Lam Phu, Udon Thani, Khon Kaen, Ubon Ratchathani, Kalasin and Roi Et because the areas in their Changwat as mentioned used to have the backgrounds of raising a large number of water buffaloes. At present their numbers have greatly decreased because the rice farmers have mostly turned to use ploughing machines instead. The state sector gives very limited importance to conservation and development of the indigenous knowledge concerning the use of water buffaloes. The people of new generation are not interested in adherence to the indigenous knowledge (Cardoso, 2009).

\section{ACKNOWLEDGEMENT}

The researchers express their sincere appreciation for all of support provided.

\section{REFERENCES}

Cardoso, D.C., M.P. Cristiano and C.O. Arent, 2009. Development of new didactic materials for teaching science and biology: The importance of the new education practices. OnLine J. Biol. Sci., 9: 1-5. DOI: $10.3844 /$ ojbsci.2009.1.5

Arayesh, B. and S.J. Hosseini, 2010. Regression analysis of effective factor on people participation in protecting, revitalizing, developing and using renewable natural resources in ilam province from the view of users. Am. J. Agric. Biol. Sci., 5: 228234. DOI: 10.3844/ajabssp.2010.228.234

Movahedi, R., H. Fathi, M. Aazami and S. Latifi, 2011. Exploring alternative solutions regarding conservation agriculture. Am. J. Agric. Biol. Sci., 6: 105-109. DOI: 10.3844/ajabssp.2011.105.109 